\title{
To be or not to be a carcinogen; delving into the glyphosate classification controversy
}

\author{
Francisco José Roma Paumgartten ${ }^{1}$
}

\begin{abstract}
${ }^{1}$ Laboratory of Environmental Toxicology, Department of Biological Sciences, National School of Public Health, Oswaldo Cruz Foundation, Rio de Janeiro, Rio de Janeiro, Brazil.
\end{abstract}

\begin{abstract}
The International Agency for Research on Cancer (IARC) placed the most widely used herbicide glyphosate (GLY) into the category 2A (probably carcinogenic to humans), a classification questioned by experts from academia and industry. This article critically appraised the epidemiological and experimental data that led the IARC working group (WG) to consider GLY a probable human carcinogen and the ensuing controversy. An association of GLY with non-Hodgkin lymphoma was suggested by some observational studies. A non-causal explanation for this weak association, however, cannot be excluded. Contrary to WG's view, long-term rodent assays yielded no convincing evidence that GLY is carcinogenic. The mechanistic evidence remains elusive as well. Bacterial reverse mutation tests (including tester strains sensitive to oxidative mutagens) were clearly negative, and so were rodent genotoxicity assays by oral route. Tests with mammalian cells in vitro yielded conflicting results at high (cytotoxic) concentrations of GLY-based formulations. Conflicting results were also obtained when high doses of GLY-based herbicides were administered to rodents by the intraperitoneal route. Such high doses are unlikely to be attained in realistic scenarios of exposure. Finally, the IARC classification is based on a conjectural hazard, and rational public health interventions must be based on estimated risks.
\end{abstract}

Keywords: Pesticides/ toxicity. Glyphosate/ adverse effects. Carcinogens. Cancer risk. Hazard/adverse effects. Genotoxicity/prevention and control.

\section{INTRODUCTION}

Glyphosate (GLY) (Figure 1) is a broadspectrum herbicide that acts by inhibiting EPSPS (5-enolpyruvylshikimate-3-phosphate synthase) a key enzyme that mediates the aromatic amino acid synthesis (shikimate) pathway in plants. In Brazil and in other soybean producing countries, the use of GLY dramatically increased after the introduction of GLY-resistant GMsoybean crop varieties in the 1990 s. Since the general population is widely exposed to trace amounts of GLY in food products, and a number of pesticide applicators are heavily exposed to GLY-based herbicides, any concerns about GLY-mediated adverse effects on health need to be properly clarified. Along this line, this review article addresses the current controversy on whether GLY has (or has not) the potential to cause cancer in humans.

Correspondence: F.J.R. Paumgartten. Laboratório de Toxicologia Ambiental, Escola Nacional de Saúde Pública (ENSP), FIOCRUZ, Prédio de Expansão do Campus (EXCAM). Av Brasil 4036, salas 101-104, 913. Rio de Janeiro, RJ 21040-361, Brasil. E-mail: paum@ensp.fiocruz.br

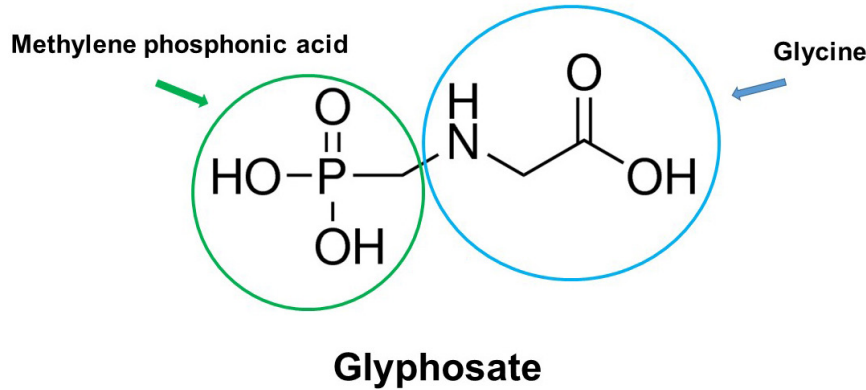 \\ FIGURE 1 - Glyphosate (GLY) or $N$-(phosphonomethyl)glycine (molecular mass: 169.07) is the most widely used herbicide in Brazil and elsewhere. GLY molecule consists of two moieties (glycine and methylene phosphonic acid) which don't carry any genotoxic alert and have no oxidative reactivity. After absorption in the GI tract, GLY undergoes no subsequent biotransformation \\ and is excreted (unchanged) in the urine.}


Research on Cancer (IARC) assessed glyphosate (GLY) as probably carcinogenic to humans (Group 2A) (Guyton et al., 2015; IARC, 2015). Afterwards, in November 2015, an assessment by the European Food Safety Authority (EFSA) concluded that: "...glyphosate is unlikely to pose a carcinogenic hazard to humans and the evidence does not support classification with regard to its carcinogenic potential according to Regulation (EC) No. 1272/2008" (EFSA, 2015). The same conclusion was reached by the JMPR (Joint FAO/WHO Meeting on Pesticide Residues) meeting held in May 2016: "... glyphosate is unlikely to pose carcinogenic risks to humans from exposure through the diet" (JMPR, 2016). Likewise, a risk assessment carried out by the US EPA arrived at the conclusion that "... glyphosate is not likely to be carcinogenic to humans" (EPA, 2017). Moreover, the European Chemicals Agency (ECHA), the German Federal Institute for Risk Assessment (BfR Bundesinstitut für Risikobewertung), the Canadian Pest Management Regulatory Agency (PMRA), the Australian Pesticides and Veterinary Medicines Authority (APVMA), the Japanese Food Safety Commission, and the EPA New Zealand (BfR, 2017) endorsed the conclusion that GLY poses no carcinogenic risks to humans.

It is of note that, as stated in the preamble to the monographs, IARC only evaluates data that were made publicly available (IARC, 2015), whereas assessments by regulatory agencies (e.g., ECHA, JMPR, EFSA and USEPA) are based on a more complete dataset that includes unpublished data from studies performed by the pesticide industry. The incompleteness of the evaluated dataset, however, is not the only explanation for divergences between the IARC and other agencies regarding GLY carcinogenicity.

The disagreement between the IARC and regulatory agencies over the carcinogenicity of GLY was promptly echoed by many experts in academia and industry, and gave rise to reviews, letters and position papers (Boobis et al., 2016; 2017; Portier et al., 2016; Loomis et al., 2017; Portier, Clausing, 2017; Tarazona et al., 2017a; b).

The debate sparked by the classification of GLY as a probable carcinogen extended beyond the particular case of this herbicide and brought into question the IARC's hazard-based classification scheme for carcinogenicity. In June 2016 the Lancet Oncology published an editorial ("When is a carcinogen not a carcinogen?") addressing the problem of "determining reliable findings when data are equivocal and there are vested interests", and the difficulties of "translating carcinogenicity research into appropriate health policies and recommendations for risk management" (When ..., 2016).
In the following lines, we analyze the strength of the experimental and epidemiological evidence supporting IARC's view that GLY is "probably carcinogenic to humans". The evidence evaluated by the IARC working group (WG) was presented and discussed at length in the Monograph 112, while the agency's classification scheme and its rationale was described in the preamble to the monograph (IARC, 2015).

\section{GLYPHOSATE CARCINOGENICITY, WHAT SAYS THE EVIDENCE?}

\section{Evidence in humans}

The evidence in humans came from observational studies showing an increased risk of non-Hodgkin lymphoma and B-cell lymphoma among exposed workers (Guyton et al., 2015; IARC, 2015). A meta-analysis of investigations on the association of non-Hodgkin lymphoma (NHL) with occupational exposure to pesticides, authored by IARC epidemiologists (Schinasi, Leon, 2014), illustrates the type and strength of the evidence in humans that led the WG to place GLY into the 2A category (Figure 2). Three case-control studies (Hardell, Eriksson, Nordstrom, 2002; De Roos et al., 2003; Eriksson et al., 2008) found an association of NHL with GLY whereas three others found no association (McDuffie et al., 2001, De Roos et al., 2005; Orsi et al., 2009). The meta-analysis risk ratio estimate (and 95\% CI) of association between GLY and NHL was 1.5 (1.1-2.0), yet the variability across studies due to heterogeneity was moderately large $\left(I^{2}=32.7 \%\right)$. The meta-analysis risk ratio (RR) estimate $(95 \% \mathrm{CI})$ for (NHL subtype) B-cell lymphoma (2 studies) was 2.0 (1.1-3.6) (Schinasi, Leon, 2014). Notwithstanding the fact that the association was weak, and the inconsistency across studies due to heterogeneity, the WG arrived at the conclusion that there was "limited" evidence in humans that GLY is carcinogenic. A further meta-analysis revealed weak and marginally significant associations between "any" versus "no" use of GLY and NHL (meta-RR=1.3, 1.0-1.6 for 6 studies) and multiple myeloma (meta- RR=1.4, 1.0-1.9, 4 studies) (Chang, Delzell, 2016). Associations were null for Hodgkin lymphoma, leukemia, and NHL subtypes except B-lymphoma (2 or 3 studies each).

A large prospective cohort of licensed pesticide applicators (54 251 applicators from North Carolina and Iowa in the US) revealed no association between GLY and any solid tumors or lymphoid malignancies overall, including NHL and its subtypes. Nonetheless, an apparently increased risk of acute myeloid leukemia 
among the most heavily exposed GLY applicators requires further confirmation (Andreotti et al., 2018).

As informed in the preamble to the monograph, the evidence in humans is classified as "sufficient", "limited", "inadequate", or "suggesting lack of carcinogenicity". It is "limited" if "... causal association is considered by the Working Group to be credible, but chance, bias or confounding could not be ruled out with reasonable confidence", and "inadequate" if "... available studies are of insufficient quality, consistency or statistical power to permit a conclusion regarding the presence or absence of a causal association ...".

Actually, if bias and confounding cannot be ruled out, one cannot exclude with reasonable confidence a non-causal explanation for the observed association. That association does not imply causation is a "mantra" of analytical epidemiology. Austin Bradford Hill, in his remarkable comment on the topic, listed the aspects that should be considered before excluding non-causal explanations for observed associations (Hill, 1965). The strength of the association ranked first in Hill's list and Richard Doll made it clear that, when relative risks are small, of the order of 2:1 or even less, the problems of eliminating bias and confounding are immense and may require massive data (Doll, 2002). In contrast with experimental investigations, in observational studies systematic errors (biases and confounding) are often more relevant than the random error. Moreover, in addition to being weak, the associations between GLY and some lymphohematopoietic cancers lacked consistency and specificity; i.e., the association with one particular type of cancer has not been consistently detected across studies. Whether the evidence is "limited" or "inadequate", therefore, depends ultimately on a subjective judgment that may be influenced by WG members' aprioristic beliefs (How "credible" is the notion that observed associations are causal?).

\section{Evidence in experimental animals}

The WG conclusion that there was sufficient evidence in animals that GLY poses a carcinogenic hazard stands basically on findings from long-term studies in mice (dietary administration, 2 studies) and rats (diet, 2 studies). Detailed reports by the EPA on study findings were the primary source of the data analyzed by the WG (IARC, 2015).

Mouse. In one CD-1 mouse study (24 months, 50 $\mathrm{M}$ and $50 \mathrm{~F} /$ group, 24 months, GLY: 0, 1000,5000 or 30 $000 \mathrm{ppm}$ ) the increasing levels of the herbicide in the diet induced a positive trend in the incidence of renal tubule carcinoma in males $(0 / 49,0 / 49,1 / 50,2 / 50)$. Another study in CD-1 mice (104 weeks, $50 \mathrm{M}$ and $50 \mathrm{~F} /$ group, GLY: 0, $100,300,1000 \mathrm{mg} / \mathrm{kg}$ body weight/day) found a positive trend for hemangiosarcoma in males $(0 / 50,0 / 50,0 / 50$, $4 / 50)$ but not in females $(0 / 50,2 / 50,0 / 50,1 / 50)$. It is of note that, although being conducted with the same CD-1 mouse strain, the second study failed to reproduce the positive trend for renal tubule carcinoma observed in the first study and vice versa (i.e., for hemangiosarcoma). In other words, the two mouse studies did not confirm each other's findings.

EVIDENCE IN EXPERIMENTAL ANIMALS



\begin{tabular}{|l|}
\hline Group 1 Carcinogenic to humans \\
\hline Group 2A Probably carcinogenic \\
\hline Group 2B Possibly carcinogenic \\
\hline Group 3 Not classifiable \\
\hline Group 4 Probably not carcinogenic \\
\hline
\end{tabular}

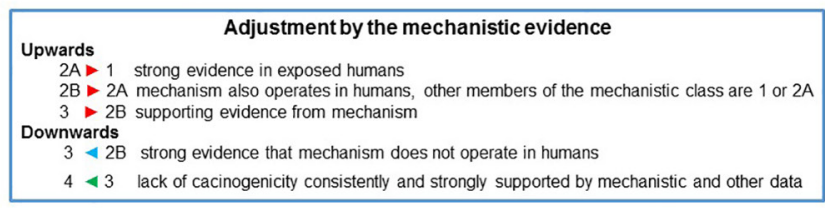

FIGURE 2 - IARC's cancer hazard-based classifcation scheme. The classification into a cancer-hazard category (Group 1, 2A, 2B, 3 or 4 ) relies fundamentally on a separate assessment of the evidence in humans and in animals. The IARC overall cancer-hazard category may be adjusted upwards or downwards depending on the strength of the evidence on the underlying mechanisms of carcinogenesis and whether or not they are likely to operate in humans. 
Rat. A Sprague-Dawley rat study (24 months, $60 \mathrm{M}$ and $60 \mathrm{~F} /$ group, 10 rats/group euthanized after 12 months, GLY: 0, 2000,8000 or $20000 \mathrm{ppm}$ ) found a non-dose related increase in pancreas islet cell adenomas in males (M: 1/58, 8/57, 5/60, 7/59; F: 5/60, 1/60, 4/60, 0/60) and no increase in islet cell carcinomas (M: $1 / 58,0 / 57,0 / 60$, $0 / 59 ; \mathrm{F} ; 0 / 60,0 / 60,0 / 60,0 / 59)$. A second study in SpragueDawley rats (life time exposure up to 26 months, $50 \mathrm{M}$ and $50 \mathrm{~F}$ /group, GLY: 0, 30, 100 or $300 \mathrm{ppm}$, or $0,3,10$ or $31 \mathrm{mg} / \mathrm{kg}$ body weight/day) yielded a similar result for pancreatic islet cell adenomas (M: 0/50, 5/49, 2/50, 2/50; F: $2 / 50,1 / 50,1 / 50,0 / 50)$ and carcinomas (M: 0/50, 0/49, 0/50, 1/50; F:0/50, 1/50, 1/50, 1/50).

Two other long-term (24 months) studies in SpragueDawley (Séralini et al., 2014) and Wistar (Chruścielska et al., 2000) rats, in which GLY-based formulations were given via drinking water, showed no significant increase in tumor incidence in any treated group. Owing to methodological deficiencies and incompleteness of study reports, the WG considered the evidence from these studies inadequate for the evaluation of GLY.

The occurrence of pancreatic islet cell adenomas was consistently noted in male and female rats in both studies evaluated by the WG (EPA report), yet it was also recorded in untreated animals and, among the treated ones, the incidence was unrelated to the dose of GLY. Moreover, as commented by Williams et al. (2016a, b), pancreatic islet cell adenoma is a relatively common tumor in rats (a non-malignant lesion) and, in the two studies, there was no indication of progression to islet cell carcinoma.

In one of the two rat studies, a significant trend of increase in hepatocellular adenomas and thyroid $\mathrm{C}$-cell adenomas was observed. Both lesions, however, occurred also in untreated animals (they are relatively common histopathology findings in rats), and there was no indication of progression to carcinomas.

In summary, we do believe, and so many other experts do (Williams et al., 2016a; Tarazona et al., 2017a), that the WG over-interpreted the available data when their members deemed that long-term rodent studies provided "sufficient" evidence of GLY carcinogenicity.

\section{Evidence on possible underlying mechanisms}

Although the classification of an agent into one of the 5 categories stands primarily on the cancer data in exposed humans (epidemiology studies) and animals (long-term carcinogenicity assays), the overall rating may be adjusted upwards or downwards depending on the strength of the evidence on the potential underlying mechanisms and whether or not they are likely to operate in humans (Figure 2).

\section{Genetic damage}

Based on the evaluation of three cytogenetic biomonitoring studies in exposed humans and a very large number of studies in mammalian cells in vitro and in experimental animals, the WG concluded that there was "strong evidence that exposure to GLY or GLY-based formulation is genotoxic" (IARC, 2015). This notion is at odds with the conclusion reached by a comprehensive review of the data on the genotoxic potential of GLY that included a set of unpublished regulatory studies (Kier, Kirkland, 2013). Moreover, it is at variance with the conclusions of a recent analysis of genotoxicity data on GLY and GLY-based formulations conducted by an expert panel (Brusick et al., 2016; Williams et al., 2016a). Kier, Kirkland (2013) noted that there was "an overwhelming preponderance of negative results in wellconducted bacterial reversion and in vivo mammalian micronucleus and chromosomal aberration assays", and that "negative results for in vitro gene mutation and a majority of negative results for chromosomal effect assays in mammalian cells" are additional indications that GLY is not typically genotoxic for these endpoints. According to the authors, reports of positive results for DNA damage endpoints in some tests indicated that GLY and GLY-based formulations tend to elicit DNA damage effects at high (and toxic) levels, and that these effects were probably secondary to cytotoxicity rather than a consequence of DNA interaction with GLY, and that the effects may be caused by surfactants present in many herbicide formulations (Kier, Kirkland, 2013). The WG, however, decided not to evaluate the data (66 unpublished regulatory studies) provided in a supplement to Kier and Kirkland's review because they would not meet the inclusion criteria laid down in the preamble to the monograph, i.e., these studies were neither "reports that have been published or accepted for publication in the openly available scientific literature" nor "governmental reports that are publicly available" (IARC, 2015).

The strength of the evidence from studies on the genotoxicity of GLY and or GLY-based formulations that were included in the IARC monograph is critically appraised in the next sections.

\section{Studies in exposed humans}

The WG evaluated three studies of genetic damage in exposed humans. Paz-y-Miño et al. (2007) noted that the incidence of DNA strand breaks (Comet assay) in blood 
TABLE I - Weaknesses of the evidence considered by the IARC working group to place glyphosate into category 2 A ("probably carcinogenic to humans")

\begin{tabular}{|c|c|c|c|}
\hline Evidence (in) & Data (from) & WG's assessment & Weaknesses of the evidence \\
\hline Humans & $\begin{array}{c}\text { Observational } \\
\text { studies } \\
\text { (case-control) }\end{array}$ & Limited & $\begin{array}{l}\text { Non-causal associations cannot be ruled out. } \\
\text { - Associations (NHL and B-cell lymphoma) were weak (meta- } \\
\text { analysis RR } \leq 2 \text { ) and only marginally significant (lower limits } \\
\text { of } 95 \% \mathrm{CI}=1 \text { or } 1.1 \text { ) } \\
\text { - Lack of consistency and specificity of findings } \\
\text { - A large prospective cohort found no association between } \\
\text { GLY and any solid tumor and lymphoid malignancies. }\end{array}$ \\
\hline
\end{tabular}

Mice:

- Statistical significance and dose-response was undemonstrated or questionable.

Rodent
Animals
carcinogenicity
assays

Rodent assays

- 02 CD-1 mouse assays did not confirm each other's tumor findings.

Sufficient Rats:

- Pancreatic islet cell adenomas, hepatocellular adenomas and thyroid $\mathrm{C}$-cell adenomas are non-malignant lesions that also occurred in untreated rats.

- No indication of adenoma progression to carcinoma.

- Bacterial reverse mutation assays (with strains sensitive to oxidative mutagens) yielded negative results.

- In vitro assays with mammalian cells gave rise to conflicting results. Positivity noted at high and cytotoxic concentrations of some formulated products.

In vitro and in vivo assays for Mechanistic genotoxicity and biomarkers of oxidative stress.
Strong - In vivo genotoxicity assays were negative when rodents were treated orally.

- In vivo assays produced conflicting results when rodents were treated by the ip route with formulated herbicide products.

- Oxidative stress and genotoxic damage noted only at concentrations (in vitro) and doses (in vivo) unattainable in any realistic scenario of human exposure to GLY-based herbicides

IARC: International Agency for Research on Cancer; NHL- Non-Hodgkin lymphoma, GLY: glyphosate, WG: IARC expert working group

cells collected from 24 people living in sprayed areas 2 weeks to 2 months after the aerial spraying of GLY was higher than the incidence determined in 21 individuals living in unsprayed areas. A limitation of Paz-y- Miño et al. (2007)'s study (and of ecological-type study designs) is that a number of possible biases and confoundings remained uncontrolled. A further study by the same group found no increase in chromosomal abnormalities in the blood cells of 92 people living in sprayed areas of northern Ecuator (compared to the incidence observed in 90 unexposed healthy individuals) two years after the last aerial spray of GLY (Paz-y-Miño et al., 2011). Bolognesi et al. (2009) evaluated the incidence of cytokinesis block micronucleus in lymphocytes from 137 women and their spouses living in Colombia regions where GLY was sprayed. Blood samples were taken prior to spraying (baseline incidence), and 5 days and 4 months after GLY spraying. The results suggested that there was a small and transient increase in the occurrence of micronucleus in lymphocytes after GLY exposure. According to Bolognesi et al. (2009), the genotoxic risk associated with GLY exposure during aerial spraying for coca and poppy eradication in Colombia was low.

\section{Bacterial (reverse mutation) assays}

Only two Salmonella typhimurium (and E.coli WP2) assays were evaluated by the WG. A study by Li, Long (1988) found no mutagenic effect (reverse mutation) of GLY (tested up to $5000 \mu \mathrm{g}$ per plate) in a standard testing battery including S.typhimurium strains TA1535, TA1537, TA1538, TA98 and TA100, and E.coli WP2, without and with extrinsic metabolic activation (rat liver 
S9). Another study by Rank et al. (1993) tested a GLY herbicide (Round up ${ }^{\circledR}$ ) in two S.typhimurium tester strains and found a positive result with TA 98 in the absence of Aroclor-induced rat liver S9 mix, and a positive response with TA 100 in the presence of S9 mix. Rank et al. (1993)'s results with TA98 and TA100, however, showed no dose-dependent responses and were not consistently reproduced in two independent tests. Rank et al.'s study, therefore, produced inconsistent and inconclusive results. Accordingly, in a summary published after the meeting, the WG stated that bacterial mutagenesis tests conducted with GLY and GLY-based formulations were negative (Guyton et al., 2015).

\section{Mammalian cell in vitro assays}

An in vitro mutagenicity test (hprt locus mutation) in Chinese hamster ovary cells $\left(\mathrm{CHO}-\mathrm{K}_{1} \mathrm{BH}_{4}\right.$ cell line), with and without metabolic activation, indicated that GLY (up to $22500 \mu \mathrm{g} / \mathrm{mL}$ ) was not genotoxic (Li, Long 1988). Nonetheless, a set of genotoxicity tests of GLY and GLYbased herbicides in mammalian cells in vitro produced conflicting results. GLY proved not to be genotoxic in the test of unscheduled DNA synthesis (Fischer 344 rat hepatocytes, $125 \mu \mathrm{g} / \mathrm{mL}$ ) (Li, Long 1988). Mañas et al. (2009) found that GLY, tested in the absence of metabolic activation, increased DNA strand breaks (comet assay) in a human hepatoma cell line (Hep-2) at a concentration as high as $3 \mathrm{mM}$ or $507.2 \mu \mathrm{g} / \mathrm{mL}$, yet it failed to enhance the incidence of chromosome aberrations (CA) in human lymphocytes in vitro, even at a concentration as high as 6 $\mathrm{mM}$ or $1015 \mu \mathrm{g} / \mathrm{mL}$ (tested levels: $0.2-6.0 \mathrm{mM}$ ). Mladinic et al. (2009), noted an increase in DNA strand breaks (standard and hOGG1 comet assay with and without S9), while a test for micronuclei formation (MN) gave rise to negative results without $\mathrm{S}$, and equivocal responses in the presence of metabolic activation (at $580 \mu \mathrm{g} / \mathrm{mL}$ ). Summarizing their results, Mladinic et al. (2009) pointed out that no clear concentration-dependent response was noted in any assay, and suggested that GLY, at human relevant concentrations, poses no significant health risk. Monroy et al. (2005) observed that GLY enhanced DNA strand breaks in human fibroblast GM38 (4 mM or 676 $\mu \mathrm{g} / \mathrm{mL})$ and fibrosarcoma HT1080 (4.75 mM or $803 \mu \mathrm{g} /$ $\mathrm{mL})$ cell lines without metabolic activation. In a human fibroblast cell line (GM5757), Lueken et al. (2004) investigated whether a set of non-genotoxic chemicals (including GLY) would interact synergistically with $\mathrm{H}_{2} \mathrm{O}_{2}$ in inducing DNA strand breaks, and obtained an equivocal response for a very high concentration of GLY (75 mM or $12680 \mu \mathrm{g} / \mathrm{mL}$; without S9). Bolognesi et al. (1997) observed an enhancement of sister chromatid exchanges (SCE) in human lymphocytes exposed in vitro (without S9) to high concentrations of GLY $(1000 \mu \mathrm{g} /$ $\mathrm{mL})$ and GLY-based products $(100 \mu \mathrm{g} / \mathrm{mL})$. Under similar experimental conditions (human lymphocytes without S9), Vigfusson, Vyse (1980) reported that Round up ${ }^{\circledR} 250 \mu \mathrm{g} /$ $\mathrm{mL}$ enhanced SCE. In an in vitro study considered by the WG as being of "limited quality", Gasnier et al. (2009) noted that a GLY-based formulation (5 ppm, without S9) increased DNA strand breaks in human liver HepG2 cells. Koller et al. (2012) found that both GLY and Round up ${ }^{\circledR}$ increased DNA strand breaks in a buccal epithelial cell line (TR146) treated with concentrations $\geq 20 \mu \mathrm{g} / \mathrm{mL}$ in the absence of S9. Alvarez-Moya et al. (2014) reported that GLY increased DNA strand breaks in human lymphocytes in vitro (without S9), yet the magnitude of the increase in tail length remained practically unchanged over a large interval of tested concentrations (from 0.7 to $0.0007 \mathrm{mM}$ ). Roustan et al. (2014) evaluated in a Chinese hamster ovary cell line (CHO-K1) whether pesticides and their mixtures caused photo-inducible cytogenetic toxicity (MN) with and without metabolic activation. GLY had no effect in the absence of $\mathrm{S} 9$, but it was clastogenic $(10 \mu \mathrm{g} / \mathrm{mL})$ when tested with metabolic activation in the dark. In another study, Lioi et al. (1998) treated bovine lymphocytes cultured in vitro (without S9) with GLY $(17 \mu \mathrm{M}$ or $3 \mu \mathrm{g} /$ $\mathrm{mL}$ ) and observed that it increased SCEs and CAs. Still in cultured bovine lymphocytes, Siviková, Dianovský (2006) noted that a GLY-based formulation $(56 \mu \mathrm{M})$ increased SCEs in the absence (but not in the presence) of S9, although it induced no CA (without S9) even at levels as high as $1120 \mu \mathrm{M}(190 \mu \mathrm{g} / \mathrm{mL})$.

In summary, the Salmonella/microsome mutagenicity assay was frankly negative while tests in mammalian cells in vitro yielded conflicting results. Most positive (clastogenic effects) findings, however, were observed at high (cytotoxic) concentrations of GLY-based formulations.

\section{Mammalian in vivo assays}

Although humans are exposed to GLY by the oral and dermal routes, and occasionally by inhalation, except for two mouse studies, the rodent genotoxicity assays evaluated by the WG used the intraperitoneal (ip) route (IARC, 2015). A dominant lethal study (EPA report) found no evidence of genotoxic effects of GLY administered by gavage ( $2000 \mathrm{mg} / \mathrm{kg}$ body weight) to CD-1 mice. Another study revealed no increase in two endpoints for clastogenicity (CA and $\mathrm{MN}$ in polychromatic erythrocytes - PCEs) in male C57BL mice treated orally with a GLYbased formulation (1080 mg/kg body weight) (Dimitrov et al., 2006). 
Seven studies investigated the genotoxicity of GLY and GLY-based formulations administered by ip injections. Bolognesi et al. (1997) reported positive genotoxic responses in male CD1 mice treated with GLY $(300 \mathrm{mg} / \mathrm{kg}$ body weight ip) or Round up ${ }^{\circledR}(\sim 300 \mathrm{mg} / \mathrm{kg}$ body weight ip) in a variety of endpoints and tests (DNA adducts and or strand breaks in the liver and kidneys and $\mathrm{MN}$ in bone marrow cells). Mañas et al. (2009) described that male and female BalbC mice treated with GLY (400 mg/kg body weight ip) showed a higher frequency of MN-PCEs in the bone marrow. Prasad et al. (2009) found an increased incidence of CA and MN-PCEs in the bone marrow of male Swiss mice treated with Round up ${ }^{\circledR}(25$ and $50 \mathrm{mg}$ / $\mathrm{kg}$ body weight ip), a treatment that was myelotoxic as indicated by a decrease in the mitotic index of bone marrow cells. In this study clastogenic and myelotoxic effects were noted at doses much lower than the lowest effective doses (LED) determined in the other positive studies (one tenth the LED or even less), and dimethylsulfoxide (DMSO) was used as a vehicle to Round up ${ }^{\circledR}$. The use of DMSO is amazing because Round up ${ }^{\circledR}$ is a water-soluble GLY-based formulation.

Peluso et al. (1998) treated male and female CD-1 mice with GLY (270 mg/kg body weight ip) or Round up ${ }^{\circledR}$ (600 $\mathrm{mg} / \mathrm{kg}$ body weight ip) and found negative responses (DNA adducts, liver and kidneys) for GLY and positive effects for the formulated product. These results led the authors to conclude that the observed DNA damage was caused by a component of the herbicide mixture other than the active ingredient (GLY).

Three other rodent studies on the genotoxic potential of GLY or GLY-based formulations given by the ip route reported negative results. Rank et al. (1993) found no clastogenic effect (MN assay) of GLY and Round up ${ }^{\circledR}$ (up to $200 \mathrm{mg} / \mathrm{kg}$ body weight ip) in male and female NMRI mice. Grisolia (2002) gave Round up ${ }^{\circledR}$ to male and female Swiss Webster mice by the ip route (up to $200 \mathrm{mg} / \mathrm{kg}$ body weight) and noted no increase in the incidence of $\mathrm{MN}$ PCEs in the bone marrow. Li, Long (1988) treated male and female Sprague-Dawley rats with GLY $(1000 \mathrm{mg} / \mathrm{kg}$ body weight, ip) and found no increase in the occurrence of CAs in bone marrow cells.

In summary, two studies involving oral administration of GLY or GLY-based formulations to mice found no evidence of genotoxicity. Nonetheless, studies in which rats or mice received ip injections of GLY or GLY-based formulations gave rise to conflicting results. A confounding variable when GLY and GLY-based formulations - at high concentrations - are injected directly into the peritoneal cavity of rodents is the potential local toxicity (irritancy) of these preparations. Ingredients with skin and mucosal irritant properties such as surfactants (e.g., polyethoxylated tallow amine, POEA) and sulfuric and phosphoric acids are often added to GLY formulations and their types and concentrations may differ among formulations (IARC, 2015).

\section{Oxidative stress}

The WG concluded that studies in animals and human cells in vitro provided "strong evidence" that GLY and GLY-based formulations can enhance intracellular levels of reactive oxygen species (ROS). Since ROS (e.g., superoxide anion, $\mathrm{O}_{2}^{-}$, hydrogen peroxide, $\mathrm{H}_{2} \mathrm{O}_{2}$, and hydroxyl radicals, $\mathrm{OH}^{-}$) can damage macromolecules (lipids, proteins and DNA), the oxidative stress (OS) may enhance mutation rates and, by doing so, cancer initiation. ROS levels and biological effects, however, seem to exhibit biphasic (hormetic) dose-responses, i.e., low levels of ROS activate signaling pathways to initiate physiological processes and adaptive responses and higher levels (OS) may damage cell lipids, proteins and DNA.

Some in vitro studies with human cells examined the effects of GLY and GLY and GLY-based formulations on OS parameters. AMTT assay with human keratinocyte cells (HaCaT) showed that GLY and GLY-based formulations are cytotoxic when applied in the $\mathrm{mM}$ concentration range $\left(\mathrm{IC}_{50} \mathrm{~s} 17-23 \mathrm{mM}\right)$, and that addition of ascorbic acid to the culture medium increased the $\mathrm{IC}_{50} \mathrm{~s}$ (Gehin et al., 2005). Using the HaCaT cell line, Elie-Caille et al. (2010) noted that GLY, at concentrations as high as $21 \mathrm{mM}$, increased the production of $\mathrm{H}_{2} \mathrm{O}_{2}$ (dichlorodihydrofluorecein diacetate assay, DCDA). George, Shukla (2013) reported that addition of a GLY formulation $(0.1 \mathrm{mM})$ to $\mathrm{HaCaT}$ cell culture medium enhanced ROS generation (DCDA), an effect that was partially antagonized by $N$-acetyl-cysteine. Chaufan, Coalova, Molina (2014) described that a GLY formulation (40 mg/L), but not GLY 95\% pure ( $900 \mathrm{mg} / \mathrm{L})$, enhanced ROS formation by the human liver HepG2 cell in culture. A subsequent study with human HEp-2 cells found that a GLY-based herbicide (Atanor ${ }^{\circledR}$ ), applied at levels as high as $376.4 \mathrm{mg} / \mathrm{L}$, induced ROS formation (DCDA), catalase activity and glutathione levels, and did not change superoxide dismutase (SOD) and gluthatione$S$-transferase (GST) activities (Coalova, Molina, Chaufan, 2014). Mladinic et al. (2009) treated human lymphocytes in vitro and noted that, with and without addition of S9, GLY $(98 \%$ pure, $580 \mu \mathrm{g} / \mathrm{mL})$ increased lipid peroxidation. Kwiatkowska, Huras, Bukowska (2014) reported that, in human lymphocytes exposed in vitro, GLY, at concentrations as high as $0.25,0.5$ and $5.0 \mathrm{mM}$, caused a 
small $(<20 \%)$ yet statistically significant enhancement of ROS formation (DCDA).

Various studies investigated whether GLY and or GLY-based formulations induce OS in rodents. Astiz, Alaniz, Marra (2009) injected GLY (10 mg/kg body weight ip), zineb or dimethoate and mixtures of these pesticides into male Wistar rats and noted changes in OS biomarkers in the blood plasma, kidney and liver, particularly among the animals treated with mixtures. Cattani et al. (2014) exposed rats to Round up ${ }^{\circledR}(1 \%$ in the drinking water) during pregancy and lactation up to postnatal day 15 and noted changes in brain (hippocampus) slices of the exposed pups (15-day old) and concluded that this herbicide formulation could lead to glutamate excitocitoxicity and OS. Two other studies evaluated OS biomarkers in mice treated ip with GLY or GLY-based formulations. Bolognesi et al. (1997) reported that GLY and GLY-based formulation $(300 \mathrm{mg} / \mathrm{kg}$ body weight ip) induced oxidative DNA damage in the liver and or kidneys of CD1 mice. Cavuşoğlu et al. (2011) described that, in Swiss mice, Round up ${ }^{\circledR}(50 \mathrm{mg} / \mathrm{kg}$ body weight ip) increased serum biomarkers of liver and kidney injury (AST, ALT, BUN and creatinine), and decreased GSH levels and enhanced malondialdehyde (MDA) concentrations in the liver and kidneys. Jasper et al. (2012) evaluated the toxicity of Round up ${ }^{\circledR}$ given orally to Swiss mice (50 and $500 \mathrm{mg}$ / $\mathrm{kg}$ body weight/day) for 15 days. The authors noted a rise in ALT, AST and $\gamma$-GT in the blood serum, and enhanced lipid peroxidation (TBARS) and reduced GSH levels in the liver of males (both doses) and females (highest dose). In a tumor promoting assay in Swiss mice, George et al. (2010) noted that a GLY formulation applied on the skin ( $25 \mathrm{mg} / \mathrm{kg}$ body weight, 3 times per week for 32 weeks) induced changes in the treated area consistent with OS.

In summary, studies with human cell lines suggested that GLY and GLY-based formulations, if added to the culture medium at concentrations in the $\mathrm{mM}$ range, may elicit OS and oxidative DNA lesions. Such levels of GLY in the extracelular medium, however, are unlikely to be attained when humans are exposed through the diet, and or during the preparation and application of GLYbased herbicides. Non-human mammalian studies, on the other hand, were conducted mostly by non-relevant routes of administration (ip) and tested unrealistic high doses. US EPA conservative estimate for exposures of the general population via food and water was $0.088 \mathrm{mg}$ of GLY/kg body weight/day (range 0.058-0.23), while for applicators, $90^{\text {th }}$ centiles for systemic exposures based on biomonitoring and dosimetry normalized for penetration through the skin were 0.0014 and $0.021 \mathrm{mg} / \mathrm{kg}$ body weight/day, respectively (Solomon, 2016). Moreover, some studies of GLY-based formulations in rodents are confounded by the substantial liver and kidney toxicity, and toxic (irritant) formulation ingredients other than GLY.

\section{The overall evidence}

The limited evidence in humans supporting WG's classification of GLY into 2A category was a positive association (marginally significant, lower limit of $95 \%$ $\mathrm{CI}=1$ or 1.1 ) between workers' exposure to GLY-based herbicides and NHL and or B-cell lymphoma detected by a meta-analysis of case-control studies. This association, however, was weak and thus a non-causal explanation for it cannot be ruled out. A further large cohort study (Andreotti et al., 2018) found no association between NHL and occupational exposure to GLY-based herbicides.

The evidence in animals, on the other hand, refers to a "positive trend" in the incidence of renal tubule carcinoma among males in one mouse study and hemangiosarcoma in male mice from another study. The two CD-1 mouse studies, however, did not reproduce each other's findings. Moreover, the statistical significance and dose-response relationships were not convincingly demonstrated (Williams et al., 2016a; b). A non-dose related increase in pancreatic islet cell adenomas was found in two rat studies. Nonetheless, these are nonmalignant lesions also found in untreated animals and no indication of progression to islet cell carcinoma was noted in both rat studies. The WG conclusion that these data provided "sufficient" evidence of carcinogenicity in animals therefore seems to be an over-interpretation of inconsistent data on the tumor occurrence in life-span exposure rodent studies.

The WG interpretation that the overall data indicated that GLY and GLY-based formulations induce "DNA and chromosomal damage in mammals" - possibly mediated by oxidative stress - was unsupported by a critical appraisal of studies' design details and findings. GLY is not an electrophilic compound (Figure 1) and results from bacterial assays, including strains sensitive to detect oxidant mutagens, were negative. The Salmonella/ microsome assay (Ames' test) is one of the most sensitive mutagenicity tests. It has yielded very few false negative results that are generally reversed when a more adequate metabolic activation system is used. Carcinogenic nitrosamines that are non-mutagenic in the standard Ames test, for instance, give a positive response when the rat liver S9 is replaced with a hamster liver S9 (Lijinsky, Andrews, 1983). There is no reason to think that GLY could be activated by an extrinsic metabolic activation system other than the rat liver S9. That is, the negative 
results of assays with a comprehensive set of bacterial tester strains, including those strains sensitive to oxidative mutagens, is a strong evidence that GLY is not mutagenic.

Overall, results from in vitro assays with mammalian cells suggested that GLY at non-toxic concentrations did not induce DNA and or chromosomal damage. Along this line, GLY proved not to be genotoxic when mice were treated orally. Conflicting results, however, were obtained when rodents received ip injections of GLY-based herbicides. In rodents treated by the ip route, changes in genotoxic endpoints were generally noted only at high doses and may have been secondary to a systemic toxicity. The contribution of ingredients of GLY-based formulations other than GLY to the clastogenic response cannot be ruled out either.

\section{CONCLUDING REMARKS}

The inclusion of GLY into IARC's 2A category was based on equivocal data provided by a set of investigations which are predominantly non-GLP studies. As far as public health is concerned, however, the heated dispute on whether GLY might eventually pose a cancer hazard is much ado about nothing. Actually, from a pragmatic standpoint, cost-effective public health interventions have to be based on the estimated risks (probability to cause harm) and not on a conjecture about the potential to cause harm. To estimate carcinogenic risks to humans, additional terms such as exposure and dose-response relationship must be brought into the equation. Along this line, most of the findings that led the WG to infer that GLY (probably) poses a cancer hazard were noted only at concentrations (in vitro assays) or doses (in vivo studies) unattainable in any realistic scenario of human exposure. A biomonitoring study detected urinary levels of GLY (24-h samples) in $60 \%$ of the exposed farmers, $4 \%$ of their spouses and $12 \%$ of their children on the day of application. The authors found that the mean concentration of GLY in the urine was $3 \mathrm{ppb}$ with a maximum level of $233 \mathrm{ppb}$, and that farmers who did not wear gloves had GLY levels much higher than those who used this item of individual protective equipment (10 versus $2 \mathrm{ppb}$ ) (Acquavella et al., 2004; Araujo, Delgado, Paumgartten, 2016). Data from biomonitoring studies, therefore, revealed that, even for the most heavily exposed people, exposures to GLY were less than the reference dose and the acceptable daily intakes (Acquavella et al., 2004; Solomon, 2016).

A warning in the preamble (monograph 112) stresses that classification refers to a speculative cancer hazard (e.g., "possible" or "probable" carcinogenicity to humans). Notwithstanding reiterating the caveat, IARC has maintained the term "risk" in the title of the monograph series ("IARC Monographs on the Evaluation of Carcinogenic Risks to Humans") leaving a room for misinterpretation.

Although a monograph elaborated by a group of experts adds to the literature available for decision makers, the purpose and usefulness of cancer hazard-based classification categories remain unclear. In a response to a criticism about the IARC classification scheme (Boobis et al., 2016), experts from the agency staff (Loomis et al., 2017) argued that hazard identification provides "..a vital platform for the subsequent steps of risk assessment and management". There is no doubt that hazard identification is the initial step of risk assessment and management. Summarizing and translating all the available data into a cancer hazard category, however, is worthless for a subsequent risk assessment. Furthermore, a cancer hazardbased classification may mislead risk communication and decision-making by national regulatory authorities who have no technical skills and capabilities to conduct an independent risk assessment.

\section{ACKNOWLEDGMENTS}

The author has no potential conflicts of interest related to the subject of this article. The author's research projects were supported by FAPERJ, CNPq and ENSPFIOCRUZ.

\section{REFERENCES}

Acquavella JF, Alexander BH, Mandel JS, Gustin C, Baker B, Chapman P, et al. Glyphosate biomonitoring for farmers and their families: results from the Farm Family Exposure Study. Environ Health Perspect. 2004;112(3):321-6.

Alvarez-Moya C, Silva MR, Ramírez CV, Gallardo DG, Sánchez $\mathrm{RL}$, Aguirre AC, et al. Comparison of the in vivo and in vitro genotoxicity of glyphosate isopropylamine salt in three different organisms. Genet Mol Biol. 2014;37(1):105-10.

Andreotti G, Koutros S, Hofmann JN, Sandler DP, Lubin JH, Lynch CF, et al. Glyphosate use and cancer incidence in the Agricultural Health Study. J Natl Cancer Inst. 2018;110(5):50916.

Araujo JS, Delgado IF, Paumgartten FJ. Glyphosate and adverse pregnancy outcomes, a systematic review of observational studies. BMC Public Health. 2016;16(472):1-13. 
Astiz M, Alaniz MJ, Marra CA. Antioxidant defense system in rats simultaneously intoxicated with agrochemicals. Environ Toxicol Pharmacol. 2009;28(3):465-73.

BfR, Bundesinstitut für Risikobewertung. Glyphosate assessment: BfR rejects plagiarism accusations. 2017 [cited on 2018 Jan $5^{\text {th }}$ ] Available from: http://www.bfr.bund.de/en/ press_information/2017/34/glyphosate_assessment_bfr_ rejects_plagiarism_accusations-201890.html

Bolognesi C, Bonatti S, Degan P, Gallerani E, Peluso M, Rabboni R, et al. Genotoxic activity of Glyphosate and its technical formulation roundup. J Agric Food Chem. 1997;45(5):1957-196. doi: 10.1021/jf9606518.

Bolognesi C, Carrasquilla G, Volpi S, Solomon KR, Marshall EJ. Biomonitoring of genotoxic risk in agricultural workers from five colombian regions: association to occupational exposure to glyphosate. J Toxicol Environ Health A. 2009;72(15/16):986-97. doi: 10.1080/15287390902929741.

Boobis AR, Cohen SM, Dellarco VL, Doe JE, Fenner-Crisp PA, Moretto A, et al. Classification schemes for carcinogenicity based on hazard-identification have become outmoded and serve neither science nor society. Regul Toxicol Pharmacol. 2016;82:158-166. doi:10.1016/j.yrtph.2016.10.014.

Boobis AR, Cohen SM, Dellarco VL, Doe JE, Fenner-Crisp PA, Moretto A, et al. Response to Loomis et al Comment on Boobis et al. Regul Toxicol Pharmacol. 2017;88:358-9. doi:10.1016/j. yrtph.2017.02.011.

Brusick D, Aardema M, Kier L, Kirkland D, Williams G. Genotoxicity Expert Panel review: weight of evidence evaluation of the genotoxicity of glyphosate, glyphosate-based formulations, and aminomethylphosphonic acid. Crit Rev Toxicol. 2016;46(suppl1):56-74.

Cattani D, Cavalli VLLO, Heinz Rieg CE, Domingues JT, DalCim T, Tasca CI, et al. Mechanisms underlying the neurotoxicity induced by glyphosate-based herbicide in immature rat hippocampus: involvement of glutamate excitotoxicity. Toxicology. 2014;320:34-45.

Cavuşoğlu K, Yapar K, Oruç E, Yalçın E. Protective effect of Ginkgo biloba L. leaf extract against glyphosate toxicity in Swiss albino mice. J Med Food. 2011;14(10):1263-72. doi: 10.1089/jmf.2010.0202.
Chang ET, Delzell E. Systematic review and meta-analysis of glyphosate exposure and risk of lymphohematopoietic cancers. J Environ Sci Health B. 2016;51(6):402-34. doi: 10.1080/03601234.2016.1142748.

Chaufan G, Coalova I, Molina MCR. Glyphosate commercial formulation causes cytotoxicity, oxidative effects, and apoptosis on human cells: diferences with its active ingredient. Int J Toxicol. 2014;33(1):29-38.

Chruścielska K, Brzezinski J, Kita K, Kalhorn D, Kita I, Graffstein B, et al. Glyphosate-evaluation of chronic activity and possible far-reaching effects. Part 1. Studies on chronic toxicity. Pestycydy (Warsaw) 2000;3/4:11-20.

Coalova I, Molina MCR, Chaufan G. Influence of the spray adjuvante on the toxicity effects of a glyphosate formulation. Toxicol In Vitro. 2014;28(7):1306-11.

De Roos AJ, Zahm SH, Cantor KP, Weisenburger DD, Holmes FF, Burmeister LF, et al. Integrative assessment of multiple pesticides as risk factors for non-Hodgkin's lymphoma among men. Occup Environ Med. 2003;60(9 E11):1-9.

De Roos AJ, Blair A, Rusiecki JA, Hoppin JA, Svec M, Dosemeci $\mathrm{M}$, et al. Cancer incidence among glyphosate-exposed pesticide applicators in the Agricultural Health Study. Environ Health Perspect. 2005;113(1):49-54.

Dimitrov BD, Gadeva PG, Benova DK, Bineva MV. Comparative genotoxicity of the herbicides Roundup, Stomp and Reglone in plant and mammalian test systems. Mutagenesis. 2006;21(6):375-82.

Doll R. Proof of causality: deduction from epidemiological observation. Perspect Biol Med. 2002;45(4):499-515.

EFSA (European Food Safety Authority). Conclusion on the peer review of the pesticide risk assessment of the active substance glyphosate. EFSA J. 2015;13(11):4302.

Elie-Caille C, Heu C, Guyon C, Nicod L. Morphological damages of a glyphosate-treated human keratinocyte cell line revealed by a micro- to nanoscale microscopic investigation. Cell Biol Toxicol. 2010;26(4):331-9.

EPA (US Environmental Protection Agency). EPA Releases Draft Risk Assessments for Glyphosate. 2017 [cited on 2018 Jan $4^{\text {th }}$ ] Available from: https://www.epa.gov/pesticides/epareleases-draft-risk-assessments-glyphosate. 
Eriksson M, Hardell L, Carlberg M, Akerman M. Pesticide exposure as risk factor for non-Hodgkin lymphoma including histopathological subgroup analysis. Int J Cancer. 2008;123(7):1657-63.

Gasnier C, Dumont C, Benachour N, Clair E, Chagnon MC, Séralini GE. Glyphosate-based herbicides are toxic and endocrine disruptors in human cell lines. Toxicology. 2009;262(3):184-91.

Gehin A, Guillaume YC, Millet J, Guyon C, Nicod L. Vitamins $\mathrm{C}$ and $\mathrm{E}$ reverse effect of herbicide-induced toxicity on human epidermal cells HaCaT: a biochemometric approach. Int J Pharm. 2005;288(2):219-26.

George J, Prasad S, Mahmood Z, Shukla Y. Studies on glyphosate-induced carcinogenicity in mouse skin: a proteomic approach. J Proteomics. 2010;73(5):951-64.

George J, Shukla Y. Emptying of intracellular calcium pool and oxidative stress imbalance are associated with the glyphosateinduced proliferation in human skin keratinocytes HaCaT cells. ISRN Dermatol. 2013;2013(art.825180):1-12.

Grisolia CK. A comparison between mouse and fish micronucleus test using cyclophosphamide, mitomycin $\mathrm{C}$ and various pesticides. Mutat Res. 2002;518(2):145-50.

Guyton KZ, Loomis D, Grosse Y, El Ghissassi F, BenbrahimTallaa L, Guha N, et al. Carcinogenicity of tetrachlorvinphos, parathion, malathion, diazinon, and glyphosate. Lancet Oncol.2015;16(5):490-1.

Hardell L, Eriksson M, Nordstrom M. Exposure to pesticides as risk factor for non-Hodgkin's lymphoma and hairy cell leukemia: pooled analysis of two Swedish case-control studies. Leuk Lymphoma. 2002;43(5):1043-9.

Hill AB. The environment and disease: association or causation? Proc R Soc Med. 1965;58:295-300.

IARC. Glyphosate. In: IARC Monograph on the Evaluation of Carcinogenic Risks to Humans. Volume 112. Some Organophosphates Insecticides and Herbicides: Diazinon, Glyphosate, Malathion, Parathion and Tetrachorvinphos; International Agency for Research on Cancer (IARC), Lyon, France; 2015.
Jasper R, Locatelli GO, Pilati C, Locatelli C. Evaluation of biochemical, hematological and oxidative parameters in mice exposed to the herbicide glyphosate-Roundup(®). Interdiscip Toxicol. 2012;5(3):133-40.

JMPR (Joint Food and Agriculture Organization of the United Nations/ World Health Organization Meeting on Pesticide Residues). Joint FAO/WHO Meeting on Pesticides Residues Geneva, 9-13 May 2016 Summary report. [cited on 2018 Jan $4^{\text {th }}$ ] Available from: http://www.who.int/foodsafety/ jmprsummary2016.pdf?ua=1.

Kier LD, Kirkland DJ. Review of genotoxicity studies of glyphosate and glyphosate-based formulations. Crit Rev Toxicol. 2013;43(4):283-315.

Koller VJ, Fürhacker M, Nersesyan A, Mišík M, Eisenbauer M, Knasmueller S. Cytotoxic and DNA-damaging properties of glyphosate and Roundup in human-derived buccal epithelial cells. Arch Toxicol. 2012;86(5):805-13. doi:10.1007/s00204012-0804-8.

Kwiatkowska M, Huras B, Bukowska B. The effect of metabolites and impurities of glyphosate on human erythrocytes (in vitro). Pestic Biochem Physiol. 2014;109:34-43.

Li AP, Long TJ. An evaluation of the genotoxic potential of glyphosate. Fundam Appl Toxicol. 1988;10(3):537-46.

Lijinsky W, Andrews AW. The superiority of hamster liver microsomal fraction for activating nitrosamines to mutagens in Salmonella typhimurium. Mutat Res. 1983;111(2):135-44.

Lioi MB, Scarfì MR, Santoro A, Barbieri R, Zeni O, Di Berardino D, et al. Genotoxicity and oxidative stress induced by pesticide exposure in bovine lymphocyte cultures in vitro. Mutat Res. 1998;403(1-2):13-20.

Loomis D, Guyton KZ, Straif K, Wild CP. Classification schemes for carcinogenicity based on hazard identification serve science and society. Regul Toxicol Pharmacol. 2017;88:356-357.

Lueken A, Juhl-Strauss U, Krieger G, Witte I. Synergistic DNA damage by oxidative stress (induced by $\mathrm{H}_{2} \mathrm{O}_{2}$ ) and nongenotoxic environmental chemicals in human fibroblasts. Toxicol Lett. 2004;147(1):35-43.

Mañas F, Peralta L, Raviolo J, Ovando HG, Weyers A, Ugnia L, et al. Genotoxicity of glyphosate assessed by the comet assay and cytogenetic tests. Environ Toxicol Pharmacol. 2009;28(1):37-41. 
McDuffie HH, Pahwa P, McLaughlin JR, Spinelli JJ, Fincham $\mathrm{S}$, Dosman JA, et al. Non-Hodgkin's lymphoma and specific pesticide exposures in men: cross-Canada study of pesticides and health. Cancer Epidemiol Biomarkers Prev. 2001;10(11):115563.

Mladinic M, Berend S, Vrdoljak AL, Kopjar N, Radic B, Zeljezic D. Evaluation of genome damage and its relation to oxidative stress induced by glyphosate in human lymphocytes in vitro. Environ Mol Mutagen. 2009;50(9):800-7.

Monroy CM, Cortés AC, Sicard DM, Restrepo HG. Citotoxicidad y genotoxicidad en células humanas expuestas in vitro a glifosato. Biomédica 2005;25(3):335-45.

Orsi L, Delabre L, Monnereau A, Delval P, Berthou C, Fenaux $\mathrm{P}$, et al. Occupational exposure to pesticides and lymphoid neoplasms among men: results of a French case-control study. Occup Environ Med. 2009;66(5):291-8. doi:10.1136/ oem.2008.040972.

Paz-y-Miño C, Sánchez ME, Arévalo M, Muñoz MJ, Witte T, De-la-Carrera GO, et al. Evaluation of DNA damage in na Ecuator population exposed to glyphosate. Genet Mol Biol. 2007;30(2):456-60.

Paz-y-Miño C, Muñoz MJ, Maldonado A, Valladares C, Cumbal $\mathrm{N}$, Herrera $\mathrm{C}$, et al. Baseline determination in social, health, and genetic areas in communities affected by glyphosate aerial spraying on the northeastern Ecuadorian border. Rev Environ Health. 2011;26(1):45-51.

Peluso M, Munnia A, Bolognesi C, Parodi S. 32P-postlabeling detection of DNA adducts in mice treated with the herbicide Roundup. Environ Mol Mutagen.1998;31(1):55-9.

Portier CJ, Armstrong BK, Baguley BC, Baur X, Belyaev I, Bellé $\mathrm{R}$, et al. Differences in the carcinogenic evaluation of glyphosate between the International Agency for Research on Cancer (IARC) and the European Food Safety Authority (EFSA). J Epidemiol Community Health. 2016;70(8):741-5.

Portier CJ, Clausing P. Re: Tarazona et al. (2017): Glyphosate toxicity and carcinogenicity: a review of the scientific basis of the European Union assessment and its differences with IARC. Arch Toxicol. 2017;91(9):3195-7.

Prasad S, Srivastava S, Singh M, Shukla Y. Clastogenic effects of glyphosate in bone marrow cells of Swiss albino mice. J. Toxicol. 2009;2009(art.308985):1-6.
Rank J, Jensen AG, Skov B, Pedersen LH, Jensen K. Genotoxicity testing of the herbicide Roundup and its active ingredient glyphosate isopropylamine using the mouse bone marrow micronucleus test, Salmonella mutagenicity test, and Allium anaphase-telophase test. Mutat Res. 1993;300(1):29-36.

Roustan A, Aye M, De Meo M, Di Giorgio C. Genotoxicity of mixtures of glyphosate and atrazine and their environmental transformation products before and after photoactivation. Chemosphere. 2014;108(2014):93-100.

Schinasi L, Leon ME. Non-Hodgkin lymphoma and occupational exposure to agricultural pesticide chemical groups and active ingredients: a systematic review and meta-analysis. Int J Environ Res Public Health. 2014;11(4):4449-527.

Séralini GE, Clair E, Mesnage R, Gress S, Defarge N, Malatesta $\mathrm{M}$, et al. Republished study: long-term toxicity of a Roundup herbicide and a Roundup-tolerant genetically modified maize. Environ Sci Eur. 2014;26(1):14.

Siviková K, Dianovskỳ J. Cytogenetic effect of technical glyphosate on cultivated bovine peripheral lymphocytes. Int $\mathrm{J}$ Hyg Environ Health. 2006;209(1):15-20.

Solomon KR. Glyphosate in the general population and in applicators: a critical review of studies on exposures. Crit Rev Toxicol. 2016;46(sup1):21-27.

Tarazona JV, Court-Marques D, Tiramani M, Reich H, Pfeil R, Istace $\mathrm{F}$, et al. Glyphosate toxicity and carcinogenicity: a review of the scientific basis of the European Union assessment and its differences with IARC. Arch Toxicol. 2017a;91(8): 2723-43.

Tarazona JV, Court-Marques D, Tiramani M, Reich H, Pfeil $\mathrm{R}$, Istace F, et al. Response to the reply by C. J. Portier and P. Clausing, concerning our review "Glyphosate toxicity and carcinogenicity: a review of the scientific basis of the European Union assessment and its differences with IARC". Arch Toxicol. 2017b;91(9):3199-203.

Vigfusson NV, Vyse ER. The effect of the pesticides, Dexon, Captan and Roundup, on sister-chromatid exchanges in human lymphocytes in vitro. Mutat Res. 1980;79(1):53-7.

WHEN is a carcinogen not a carcinogen? Lancet Oncol. 2016;17(6):681. [Editorial]. 
Williams GM, Aardema M, Acquavella J, Berry SC, Brusick D, Burns MM, et al. A review of the carcinogenic potential of glyphosate by four independent expert panels and comparison to the IARC assessment. Crit Rev Toxicol. 2016a;46(suppl.1):3-20.
Williams GM, Berry C, Burns M, Camargo JL, Greim H. Glyphosate rodent carcinogenicity bioassay expert panel review. Crit Rev Toxicol. 2016b;46(suppl.1):44-55.

Received for publication on $21^{\text {st }}$ March 2018 Accepted for publication on $05^{\text {th }}$ May 2018 